\title{
FISCAL ADVANTAGE OF WAQF AND THE RULE OF TAX EXEMPTION FOR CHARITABLE PURPOSES UNDER THE INCOME TAX ACT 1967
}

\author{
Nur Yuhanis Ismon* \\ Mohsin Hingun**
}

\begin{abstract}
This study explores the principle of waqf in the context of current tax policies governing waqf properties. In Islamic law, waqf is defined as charity whereby the donor endows the property in the name of Allah SWT for the benefit of the public at large. However, for tax exemption purposes, there is no specific provision in the Income Tax Act 1967 (ITA). Waqf is under the State List in the Federal Constitution and it comes under the jurisdiction of state governments. Currently, there is a misunderstanding about tax deduction in Section 44(6) and Section 44(11C) of ITA that includes waqf as a gift and gets the same tax treatment. Nevertheless, there are strong justifications which state that waqf does not fall within the scope of Section 44(6). The study will analyse the status of waqf institutions which are eligible for tax deduction and the reason why waqf does not fall within the scope of donation under section 44(6) of the ITA. The methodology used in this study is doctrinal legal research whereby the analysis focuses on the legal principle of waqf in Islamic law and the rule of tax exemption under the ITA. As a result, the study found that there is inconsistency in implementing waqf for tax rebate purposes. The recommendation of this study is that a comprehensive waqf guideline should be introduced to ensure consistent development of waqf to enhance the public interest.
\end{abstract}

Keywords: Tax, Waqf, Tax Exemption

* Doctoral Candidate, Ahmad Ibrahim Kulliyyah of Laws, International Islamic University Malaysia. Email: annyss0306@gmail.com.

** Associate Professor, Ahmad Ibrahim Kulliyyah of Laws, International Islamic University Malaysia. Email: mohsinhingun@iium.edu.my.

[Received: 1 March 2020, Accepted: 5 April 2019, Published: 30 June 2020] 


\title{
KEISTIMEWAAN FISKAL TERHADAP WAKAF DAN PRINSIP PENGECUALIAN CUKAI UNTUK TUJUAN KEBAJIKAN DI BAWAH AKTA CUKAI PENDAPATAN 1967
}

\begin{abstract}
ABSTRAK
Kajian ini menerangkan prinsip wakaf dalam konteks dasar percukaian semasa yang mengawalselia harta wakaf. Dalam undang-undang Islam, wakaf ditakrifkan sebagai amal jariah di mana penderma mendermakan harta itu atas nama Allah SWT untuk kepentingan orang ramai pada umumnya. Walaubagaimanapun, untuk tujuan pengecualian cukai tiada peruntukan khusus dalam Akta Cukai Pendapatan 1967 (ACP). Wakaf berada di bawah Senarai Negeri dalam Perlembagaan Persekutuan dan ia terletak di bawah bidang kuasa kerajaan negeri. Pada masa ini, terdapat salah faham mengenai potongan cukai dalam Seksyen 44 (6) dan Seksyen 44 (11C) ITA yang merangkumi wakaf sebagai hadiah dan mendapat layanan cukai yang sama.Namun begitu, ada alasan yang kuat menyatakan wakaf tidak termasuk dalam skop Seksyen 44 (6 ). Kajian ini akan menganalisis status institusi wakaf yang layak untuk potongan cukai dan sebab mengapa wakaf tidak termasuk dalam skop sumbangan di bawah seksyen 44 (6) ACP. Metodologi yang digunakan dalam kajian ini adalah penyelidikan undang-undang doktrin di mana analisis menumpukan kepada prinsip perundangan wakaf dalam undang-undang Islam dan peraturan pengecualian cukai di bawah ACP. Oleh yang demikian, kajian mendapati terdapat ketidakselarasan dalam melaksanakan wakaf untuk tujuan rebat cukai. Cadangan kajian ini adalah memperkenalkan garis panduan wakaf yang komprehensif untuk memastikan pembangunan wakaf yang konsisten untuk meningkatkan kepentingan awam.
\end{abstract}

Kata kunci: Cukai, Wakaf, Pengecualian Cukai

\section{INTRODUCTION}

Waqf can be defined as the preservation of a benefit-generating estate from corporal disposal by using its usufruct as benefit in charity at the time of its creation and thereafter. ${ }^{1}$ Waqf property is subject to several tax liabilities: income tax, stamp duty, real property gains tax, quit

1 Mohammad Tahir Sabit, "The Concept and Objective of Waqf". Shariah Law Reports, vol. 1, (2014); cv10. 
rent and assessment tax. This article will focus on whether tax exemption under section 44(6) of the Income Tax Act 1967 (ITA 1967) is applicable to waqf as the section is silent on matters related to waqf. ${ }^{2}$ Aside from that, this article will also touch on the power of the state authority in governing waqf under the State Islamic Enactments. Administratively, in order to get exemption from paying tax, the waqf institutions have to apply for approval under Section 44(6) of the ITA 1967. There are several waqf institutions which claimed that they had obtained permission under Section 44(6) and whoever put their cash as waqf will get a tax deduction of $7 \%$ for individuals and $10 \%$ for corporations.

Nevertheless, the Department of Tax Policies, Inland Revenue Board (IRB) argued that they have never approved any application for waqf under Section 44(6) ITA 1967. There are applications for tax deduction under this provision by waqf institutions, but the applications were rejected for various reasons. Among the reasons are the broad objective of the operation, commercial activities, and to exchange cash donations for permanent assets. On the other hand, Waqaf An Nur Corporation has obtained tax exemption from the Minister of Finance under Section 44(11c) for five years from 2015 until 2019. Due to lack of a specific provision governing tax exemption for waqf, the tax treatment is varies based on the each application because the Inland Revenue Board treats this issue on a case to case basis i.e., there is no standard tax treatment. Thus, the Inland Revenue Board should develop a comprehensive waqf guideline for tax purposes to ensure consistency of waqf contribution by individuals and corporations, while at the same time fostering public confidence in waqf among Malaysians.

2 Tengku Alina Alias, "Tax Laws Affecting Waqf in Malaysia: A comparison with the United Stated and Turkey." In 6th UUM International Legal Conference. 2011. 


\section{THE CONCEPT OF WAQF}

\section{Definition of waqf}

The term, "waqf" literally means, "confinement and prohibition,". It is derived from the Arabic word "al-waqf" (آَلَوقَقْفُ) which can be interpreted into simple English as a religious gift. It also implies that the property is 'detained', 'stood still', 'held still' and not to be transferred. "Al-Habs" (آلْحَبْسُ) or the property is 'blocked' and "AlMan'u (آلَّنَنْعُ ) by attempting to prevent this from being the asset of a third party.

According to Kahf, waqf can clearly be defined as, "holding and preventing of a maal (an asset) for the purpose of using the benefits in meeting its objectives of philanthropy". ${ }^{3}$ Kahf clearly defined waqf as the act of retaining something for the benefit of others. It is holding and preventing the property for the purpose of using the benefit in meeting philanthropic objectives.

From the legal point of view, waqf means the retention of a property so that income can be used for religious or charitable purposes. When a waqif (donor) dedicated his property as waqf, the property is detained or, is 'tied up' permanently and becomes nontransferable. ${ }^{4}$

\section{The Pillars of Waqf}

The majority of the Muslim jurists have agreed that the most salient feature of waqf is its irrevocable nature. ${ }^{5}$ It means when a waqif declares his property as waqf, then his heirs are unable to change this status. This will ensure that the waqf persists to benefit people and that the donor continues to receive rewards from Allah.

3 Monzer Kahf, "Financing the Development of Awqaf Property" American Journal of Islamic Social Sciences, 16(4), (1999); 39-68.

4 Madhubala Solanki, "Concept of Waqf Under Muslim Law”. (2017), https://www.lawctopus.com/academike/concept-waqf-muslim-law/. Accessed 12nd May 2019.

5 Al-Kasani, Ala' al-Din Abi Bakr bin Mas'ud, Badai' al-Sana'i' fi Tartib al-Shari'i', vol. 6, pp. 346-347, http://feqh.al-islam.com/ Books.asp. 
Another important pillar that the Muslim jurists have declared is that the waqf must be perpetual once it is created. ${ }^{6}$ This will prevent any interference from the government or individual over the waqf property. The Maliki School of Law allowed the creation of a waqf restricted in time or existence or series of lives at the expiry of which full ownership of the property reverts to the founder or the heirs of the founder. ${ }^{7}$

In addition, this function stems from the idea that waqfs property is transferred to Allah, although the usufruct it receives may benefit humanity. All Muslim scholars acknowledge that nobody can ever become the proprietor or alienate the property, and that waqf property is thus a 'frozen asset'. It cannot be subject to any sale, disposal, mortgage, gift, inheritance or any alienation. Waqf is inalienable unless there is a property exchange ${ }^{8}$ of equal value. ${ }^{9}$

Furthermore, in order to fix the concepts of perpetuity and inalienability, the object of waqf should be transferred by shifting it from the physical being of the subject concerned to the 'dedication' per se. This dedication considered to be the value of the subject in question, could be interpreted to mean that the value of the dedication would be perpetual and therefore immovable. The value-based capital of waqf could therefore put an end to the non-liquidity component of

6 Al-fatawa al-Hindiyah (Alamgiriya), vol 2, Kitab al-Waqf, Shurutahu. Also http://feqh.al-islam.com/Books.asp; al- Sharbini, Mughni al-Muhtaj, vol. 2, p. 485; Al-Bujairami, Sulaiman bin Umar bin Muhammad, Hashiyah al-Bujairami ala al-Minhaj, Kitab al-Waqf, Ahkam al-Waqf alMa'nawiyah, vol. 2 p. 62, http://feqh.al-islam.com/Books.asp.

7 Cattan Henry, “The Law of Waqf”. Herbert Law in the Middle East, vol. $1,(1955) ; 203-223$.

8 Also known as istibdal which means replacing a mawquf with another property or money having the same value as or higher value than the mawquf, by exchanging, purchasing, selling or any other manner in accordance with Hukum Syarak.

9 Wan Kamal Mujani andInnayah Yaakub. "Waqf for Higher Education in Malaysia: Overview on Challenges", European Journal of Multidisciplinary Studies, vol 2, no 5, (2017); 455-461. 
waqf property and the investment and production of waqf resources would be more convenient and competitive. ${ }^{10}$

\section{LEGAL AND REGULATORY FRAMEWORK OF WAQF Regulatory framework of waqf in Malaysia}

In Malaysia, on 27 March 2004, the government established a Department for Zakat, Waqf and Hajj (JAWHAR) to make the administration systematic and efficient. Nonetheless, this department has no authority to administer and manage waqf assets, but instead plays a role as a planning coordinator and observes the waqf subject matter. Apart from that, this department is an active complementary agency which aims to organise and promote the development of waqf, zakat and mal in Malaysia and also undertakes waqf development projects financed by the Government. The completed waqf development projects were handed over to the State Islamic Religious Councils (SIRCs) as custodians in their role as sole trustees of waqf in Malaysia.

Later in 2006, the "Manual Pengurusan Wakaf" or the Manual for Waqf Administration was released with the goal of providing uniform guidelines through reliable and consistent information on waqf land and increase expertise in waqf land management. ${ }^{11}$ In general, the Manual provides a detailed guidance for almost all aspects of the administration of waqf land to all states in Malaysia. The JAWHAR initiative could address some administrative issues such as the procedure and substantive provisions on waqf. ${ }^{12}$

${ }^{10}$ Haslindar Ibrahim, Afizar Amir and Tajul Arifin MAsron, "Cash waqf: An Innovative Instrument for Economic Development". International Review of Social Sciences and Humanities, vol 6, no 1, (2017); 1-7.

${ }^{11}$ Zulkifli Hasan and Muhammad Najib Abdullah, "The Investment of Waqf Land as An Instrument of Muslims' Economic Development in Malaysia", Dubai International Conference on Endowments' Investment, (2008); 4-6.

12 The paper was written during first author's visiting scholarship term in the World Bank Global Islamic Finance Development Centre, Borsa Istanbul Reşitpaşa Mahallesi,Tuncay Artun Caddesi Emirgan, 34467 İstanbul / TURKEY from 6th February to 28 February 2015. 
Subsequently on 25th March 2006, in a meeting of the National Baitulmal Coordination Committee which was organised by JAWHAR and participants the SIRCs, The Committee apparently decided that such a national waqf body should be formed to facilitate SIRCs' management of waqf matters. On 23 July 2008, JAWHAR established Yayasan Waqaf Malaysia (YWM) as the national body to coordinate and leverage waqf resources while at the same time complementing the efforts of the SIRC to achieve sustainable waqf innovations in order to ensure continuous benefits for the intended beneficiaries, the waqif or benefactor and society in general. ${ }^{13} \mathrm{In}$ addition, it also focuses exclusively on the commercial aspect of waqf. ${ }^{14}$ The relationship between the SIRCs and JAWHAR is only with regard to waqf management and control. ${ }^{15}$

In Malaysia, SIRC is the sole trustee of waqf which stipulated in Section 89 of the Administration of the Religion of Islam (State of Johor) Enactment 2003. ${ }^{16}$ The management of waqf is done by the Wakaf Management Advisory Panel (Panel Penasihat Pengurusan Wakaf) established by each SIRC. In the case of Negeri Sembilan, the panel is referred to as Waqf Administration Committee. The panel consists of the following:
i. Mufti as the chairman of the Committee
ii. Deputy of Chairman elected among the members of SIRC
iii. Secretary of SIRC

13 Ahmad, A., Muhammad, S. B., \& Kamaruzzaman, M. B, "Education development through waqf". 3rd International Conference on Islam and Higher Education, vol 13, (2012); 1-22.

${ }^{14}$ Sohaimi, M. S., and Syarqawi. "Waqf Development in Malaysia: Issues and Challenges". Jurnal Pengurusan JAWHAR, vol 2, no 1,(2008); 13-36.

15 Sulaiman, Maliah, and Muntaka Alhaji Zakari. "Efficiency and effectiveness of waqf institutions in Malaysia: toward financial sustainability." Access to finance and human development-essays on zakah, awqaf and microfinance 43 (2015).

16 Notwithstanding any clause to the contrary found in any instrument or declaration creating, governing or affecting it, the Majlis shall be the sole trustee of all waqf. 
iv. A member of Fatwa Committee named by Fatwa Committee of the State Chairman of Jabatan Hal Ehwal Agama Islam

v. Three other members appointed by SIRC, nominated by the Chairman of this committee. ${ }^{17}$

The authority of the SIRC as the sole trustee of the waqf land is specifically enshrined in the relevant state legislation. The council has the power to control and administer every movable and immovable waqf asset. It was also made clear that SIRC is the sole trustee of all waqf lands and properties in each respective state of Malaysia, whether in the form of waqf am or waqf khas, all nazr am and all trusts. The appointment of SIRC as the sole trustee of waqf property is to enable the proper administration and efficient operation of waqf so that it can produce sufficient income and revenue that could be used to fund any charitable activities. ${ }^{18}$ SIRC was also appointed to prevent different issues that may arise as a result of the appointment of independent trustees who are sometimes untrustworthy and also to avoid any interference by the heirs that could lead to the loss of waqf land and the transfer of ownership that obviously deviates from the intention of the waqif contrary to Islamic standards.

From the legal point of view, the SIRC has the absolute right to enter into agreements, purchase, hold and possess, convert, transfer and develop all the waqf lands in compliance with Islamic principles. The fact that the SIRC has the resources to develop the waqf property, it should be able to generate more revenue and boost the Muslim community's economy. SIRC can thus maintain a smart collaboration or joint venture with other Muslims, government agencies, corporate

17 Zurina Shafii, Zamir Iqbal and Mustafa Tasademir. "Governance regulatory framework for waqf in selected countries" The paper was written during first author's visiting scholarship term in the World Bank Global Islamic Finance Development Centre, Borsa Istanbul Reşitpaşa Mahallesi,Tuncay Artun Caddesi Emirgan, 34467 İstanbul / TURKEY, (2015).

${ }^{18}$ Siti Mashitoh Muhamad, "Ke arah pengurusan aset wakaf yang profesional dan berdaya maju". Bengkel Hibah dan Wakaf. YADIM and BCT Berhad, (2005). 
entities or private bodies to ensure that the properties continuously produce sustainable revenue and profits. ${ }^{19}$

\section{Legal framework for waqf in Malaysia}

The waqf framework in Malaysia is established in various laws, namely, the Federal Constitution, the National Land Code 1965 (NLC), Trustee Act 1949 (Act 208), Specific Relief Act 1950, Contracts Act 1950 and the respective Administration of Islamic Law Enactments of the various states in Malaysia. ${ }^{20}$ However, not all states have adopted specific waqf-related legislation or enactments. Therefore, the laws relating to waqf at the state level can be divided into two categories. Firstly, regulations in the state administration of Muslim law enactments and secondly, specific rules concerning to waqf..$^{21}$

The state enactments concerning waqf are as follows:

i. Waqf Prohibition Enactment 1911 in Johor

ii. Control of Waqf Enactment 1951. Perak Waqf Enactment was then updated and renamed as Perak Control of Waqf Rules $1969^{22}$.

iii. Selangor was the first state to authorize the SIRC as the manager of waqf properties in 1952 (Selangor Administration of Muslim Law Enactment, 1952).

iv. The move was then followed by Kelantan which is Kelantan Council of Religion and Malay Custom and Qadhi Courts Enactment 1953

v. Terengganu Administration of Islamic Law Enactment, 1955,

19 Mohd Afendi Mat Rani and Asmah Abdul Aziz. "Waqf Management and Administration In Malaysia: It Implementation From The Perspective of Islamic Law", Management \& Accounting Review (MAR), vol 9, no 2,(2010); 115-121.

${ }^{20}$ Nor Asiah Mohamad, Sharifah Zubaidah, and Zuraidah Ali, "Waqf Lands and Challenges from The Legal Perspectives in Malaysia", IIUM-Toyo Joint Symposium. (2012).

${ }^{21}$ Syarifah Zubaidah, "The Legal Framework of Waqf in Malaysia", 2015 Available at SSRN 2547440.

${ }^{22}$ Hisham Yaacob, "Waqf History and Legislation in Malaysia: A Contemporary Perspective". Journal of Islamic and Human Advanced Research, vol 3, no 6, (2013); 387-402. 
vi. Pahang in 1956 (Pahang Administration of the Law of the Religion of Islam Enactment, 1956),

vii. Melaka in 1959 (Malacca Administration of Muslim Law Enactment, 1959),

viii. Pulau Pinang in 1959 (Penang Administration of Muslim Law Enactment, 1959), Negeri Sembilan in 1960 (Negri Sembilan Administration of Muslim Law Enactment, 1960),

ix. Kedah in 1962 (Kedah Administration of Muslim Law Enactment, 1962),

x. Perlis in 1963 (Perlis Administration of Muslim Law Enactment, 1963),

xi. Perak in 1965 (Perak Administration of Muslim Law Enactment, 1965),

xii. Federal Territory in 1974 (Federal Territory Administration of Muslim Law Enactment, 1974),

xiii. Sabah in 1977 (Sabah Administration of Muslim Law Enactment,1977),

xiv. Johor in 1978 (Johor Administration of Islamic Law Enactment, 1978),

xv. Sarawak in 2001 (Majlis Islam Sarawak Ordinance, 2001). ${ }^{23}$

Since 1952, the legal framework prescribed that that all waqf, in accordance with Islamic law must be entrusted to the SIRCs. As far as the SIRCs are concerned, as long as all the waqf requirements are met, the asset becomes a waqf property and is therefore shifted to the SIRCs and can be registered and gazetted in the waqf records which is managed by the Waqf Registrar. ${ }^{24}$

Waqf is a state matter under the Malaysian Federal Constitution. Therefore, this is within the state governments' exclusive right to legislate on waqf matters. Such administration is made pursuant to the powers of the SIRCs under the administration of Islamic law by the respective States. Such laws generally provide for the administrative

${ }^{23}$ Che Zuina Ismail, Nor Jana Salim and Nor Jawanees Ahmad Hanafiah, "Administration and Management of Waqf Land in Malaysia: Issues and Solutions". Mediterranean Journal of Social Sciences, vol 6, no 4,(2015); 613.

${ }^{24}$ Syarifah Zubaidah and Nor Asiah Mohamed, "Legal Framework for Management of Waqf Land in Malaysia". Shariah Law Reports, vol 4,(2014); 1-23. 
structure of waqf management in those States. The Majlis is at the top of the hierarchy as a policy-making body capable of giving directions and decisions while the next body is a Wakaf Management Committee with powers to manage waqf assets.

Currently, five states have special law on waqf as enacted through their respective State Legislative Assemblies, The states are Melaka, ${ }^{25}$ Negeri Sembilan, ${ }^{26}$ Selangor, ${ }^{27}$ Perak $^{28}$ and Terengganu. ${ }^{29}$ As for the rest of the states, provisions on waqf governance, are only placed in the State Islamic Religious Enactment, except for Johor through the Wakaf Rules (Johor) 1983.

Special legislative drafting can be used as a comprehensive legal mechanism in regulating and administering all waqf-related activities as opposed to the provisions of existing law ${ }^{30}$.

\section{TAX AND WAQF IN SECTION 44(6)}

The above discussion clearly shows that under the Malaysian law, waqf matters are subject to existing tax law which falls within the purview of the Income Tax Act 1967 (ITA), Real Property Gains Tax Act 1986, and Stamp Act 1949 which are under the aegis of the Inland Revenue Board of Malaysia. Furthermore, other taxes related to waqf lands and buildings may be subjected to Quit Rent and Assessment tax which are under the state and local authorities respectively. Sale and service tax and tourism taxes are also other types of taxes which may be borne by the waqf institutions.

Tax deduction for charity has been provided in Section 44(6) of the ITA. This provision provides that a sum equal to any donation of

\footnotetext{
${ }^{25}$ Waqf (State of Malacca) Enactment 2005.

${ }^{26}$ Waqf (Negeri Sembilan) Enactment 2005.

${ }^{27}$ Waqf (State of Selangor) Enactment 2015.

${ }^{28}$ Waqf Enactment Perak 2015.

${ }^{29}$ Waqf Enactment Terengganu 2016.

${ }^{30}$ Mohd Izzat Amsyar Mohd Arif, "Akta Wakaf Penuhi Keperluan Semasa", Berita Harian Online, 5 April 2019, https://www.bharian.com.my/rencana/komentar/2019/04/549077/aktawakaf-penuhi-keperluan-semasa .
} 
money made by a person or corporation for that year to the Government, a State Government, a local authority or an institution or organization approved for the purposes of this section shall be deducted from the total income. The application tax deduction shall be submitted to the Director General by the organisation concerned. Then, the individual or corporation that contribute to charity and donation to the approved organisations will get an income tax rebate of $7 \%$ and $10 \%$ respectively.

The IRB has provided guidelines for the implementation of the authorization referred to in Section 44(6). Such guidelines help to clarify the types of companies, associations or funds that may be eligible for approval under subsection 44(6) of the Income Tax Act, 1967 and the different steps and procedure involved in the submission of applications for approval and other related matters.

With effect from the year of assessment 2001, any organisation or institution which is approved under subsection 44(6) is automatically granted tax exemption on its income excluding dividend income pursuant to paragraph 13, Schedule 6, ITA 1967. Paragraph 13, Schedule 6 of the ITA provides that tax exemption on the income, other than dividend income: of (a) an institution or organization approved for the purposes of subsection 44(6) so long as the approval remains in force; or (b) a religious institution or entity founded in Malaysia specifically for the purpose of religious worship or the advancement of religion that is not controlled or carried out primarily for profit.

Pursuant to the Finance Act 1986 A 328, the list of organisations and individuals excluded from income tax has been repealed. However, income other than dividend income from a building fund approved pursuant to Section 44(6) or from a religious institution established in Malaysia solely for religious worship or religious advancement is exempt from income tax.

The income of an authorised charitable organisation excluding dividend income will be exempt from income tax as long as the exemption status under Section 44(6) is retained or is in effect. Nevertheless, the Inland Revenue Board has placed additional provision that at least $70 \%$ of the income received in the previous year must be paid annually for charitable purposes. Failure to comply with this strict requirement would lead revocation of exemption status 
granted by the IRB under Section 44(6). With effect from year of assessment $2005,{ }^{31}$ the disbursement condition has been reduced from 70 per cent to 50 per cent.

Pursuant to the above, the nature and criteria of waqf do not fall under the requirement of donation under Section 44(6). From 2014 until 2018, every cash contribution that went through the Waqaf Malaysia Foundation entitled the donors to receive income tax exemption under Subsection 44 (11c) of the Income Tax Act 1967. However, in view of the income tax deduction approval under Subsection 44 (11c) of the ITA which expired on 31 December 2018 and has yet to receive approval for its extension, it has been informed that from 1 January 2019, all contributions to WMF are not eligible for tax exemption under the Act.

Table 1: Differences between Waqf and Donation under Section 44(6) of ITA

\begin{tabular}{|c|c|c|}
\hline Subject matter & Waqf & $\begin{array}{l}\text { Donation under } \\
\text { Section 44(6) ITA }\end{array}$ \\
\hline 1. Condition & $\begin{array}{l}\text { Principle must } \\
\text { remained }\end{array}$ & Free to use \\
\hline 2. Spending & $\begin{array}{l}\text { Only profit can be } \\
\text { utilised }\end{array}$ & $\begin{array}{l}50 \% \text { spending } \\
\text { requirement }\end{array}$ \\
\hline 3. Ownership & $\begin{array}{l}\text { Benefit can go back to } \\
\text { donor }\end{array}$ & no \\
\hline 4. Investment & $\begin{array}{l}\text { Waqf can generate } \\
\text { income from rental }\end{array}$ & $\begin{array}{l}\text { For approved objective } \\
- \text { to acquire building } \\
\text { required DGIR approval }\end{array}$ \\
\hline $\begin{array}{l}\text { 5. Types of } \\
\text { contribution }\end{array}$ & Cash and in kind & Only cash donation \\
\hline 6. Objective & $\begin{array}{l}\text { Wider scope (donor's } \\
\text { intention or istibdal) }\end{array}$ & For specific objectives \\
\hline $\begin{array}{ll}\text { 7. } & \text { Transaction } \\
\text { (Purchase } \\
\text { and disposal }\end{array}$ & Depends on donor & $\begin{array}{l}\text { Required } \\
\text { approval }\end{array}$ \\
\hline
\end{tabular}

31 Guidelines For Application Of Approval Under Subsection 44(6) Of The Income Tax Act 1967 April 2005. 


\begin{tabular}{|c|c|c|c|}
\hline & of asset) & & \\
\hline 8. & $\begin{array}{l}\text { Winding up } \\
\text { and } \\
\text { Dissolution }\end{array}$ & No transfer & $\begin{array}{l}\text { Balance donate to other } \\
\text { approved institution }\end{array}$ \\
\hline 9. & $\begin{array}{l}\text { Building } \\
\text { purposes }\end{array}$ & $\begin{array}{l}\text { Waqf for building } \\
\text { purposes not in line with } \\
\text { Section 44(6). } \\
\text { - Free to build } \\
\text { permanent and } \\
\text { sustainable assets as long } \\
\text { as there is adding value } \\
\text { to maintain the waqf } \\
\text { property }\end{array}$ & $\begin{array}{lr}\text { Require } & \text { special } \\
\text { application } & \text { and } \\
\text { documentation. } & \text { Under } \\
\text { different heading } & \end{array}$ \\
\hline
\end{tabular}

Table 1 shows the different aspects of waqf and donation under Section 44(6) ITA. The justification of above differences will be discussed below.

\section{1) Conditions}

One of the conditions of waqf is that the physical attributes of the property must be preserved but the revenues generated from waqf properties should be used for social welfare such as charity, orphanage or as specified by the donor. It is obvious from the definition that the waqf properties must be of charitable value, such as mosques, schools, hospitals and lands. ${ }^{32}$ Thus, any valuable property can become a waqf property, whether it is a liquid asset like money and shares or a fixed asset such as buildings, shops and land. Waqf is a continuously usufruct-giving property as long as its principal is retained. The preservation of the principal can result from its own

${ }^{32}$ Muhammad Akram Khan, An Introduction to Islamic Economics, (International Institute of Islamic Thought, 1994). 
presence as in the land or from the Waqif's arrangements and conditions. $^{33}$

However, there is no stringent condition for donation stipulated under Section 44(6). The principle and revenue can be used for charitable purposes.

\section{2) Spending}

As stated above, only revenue from the waqf can be utilised for the charity. The Inland Revenue Board has, however, imposed additional condition that at least 50 per cent of the income received in the previous year must be disbursed annually for charitable purposes. Failure to comply with this stringent condition will result in the IRB revoking the exemption status under Section 44(6) enjoyed by the charitable body.

\section{3) Ownership}

There is a question of whether the Waqif is the sole beneficiary or the main beneficiary or among the recipients of the Waqf s income. According to the Shafie school, when the property is handed over for waqf, the property is passed to Allah, and therefore there is no legal right to the waqif or to the beneficiary (mawquf alayh). ${ }^{34}$ The Hanafis observed that a waqf property has no owner at all, and this is the more reliable opinion according to the Shafie school. ${ }^{35}$ This practice has been approved by Abu Yusuf of the Hanafis, and this is the formal stance of the Hanafi , and a view of al-Imam Ahmad. ${ }^{36}$ Nevertheless, according to the Hanbali Schools of Law and one view of Imam

${ }^{33}$ Monzer Kahf, "Financing the Development of Awqaf property". American Journal of Islamic Social Sciences, vol 16, no 4, (1999); 39-68.

${ }^{34}$ Sheikh Sayyed Sahbeq, Figh al-Sunna [Sunni Jurisprudence] vol. 3, (Dar al-Fiker, Beirut, $2^{\text {nd }}$ ed., 1998),p 270.

${ }^{35}$ Fath al-Qadir, vol.5, 'bab al-waqf'; .

${ }^{36}$ Muhammad al-Syarbini al-Khatib, , Mughni al-Muhtaj ila Ma'rifati Ma'ani alfaz al-Minhaj, vol 2 (1997), p 376. 
Shafie, the waqif passes possession to the beneficiary by endowing the property as waqf. ${ }^{37}$

The Malikis consider it to remain in the ownership of the waqif, though he is prohibited from using it. ${ }^{38}$ Abu Zuhrah has ascribed to the Imamiyyah the view that the ownership of the waqf property remains with the waqif. ${ }^{39} \mathrm{He}$ then observes that this is the preponderant view of the Imamiyyah. ${ }^{40}$

The majority of Muslim jurists therefore argue that ownership of a waqf should not be returned to the donor himself as it contradicts the very intent of waqf. However, some of the corporate waqf procedures appoint the donor himself as the waqf's legal owner. The position of mainstream Muslim jurists on this issue finds this matter to be void as the donor could not re-own what he already owns. ${ }^{41}$

The author ${ }^{42}$ favours this opinion with regard to the practice of corporate waqf as the institutions usually do not really mean to reown the waqf asset. This method is used to give the corporate institutions total autonomy and the ability to control, distribute and channel the waqf proceeds or even use same. The institutions could use the corporate waqf proceeds for their CSR projects and recycle the proceeds to support their operations and company in certain circumstances. This was practised by Waqf An Nur Corporation Berhad in order to facilitate and improve the social role in their waqf projects such as: An Nur Mosque, Waqf An-Nur Clinic, Waqf An-

${ }^{37}$ Sheikh Sayyed Sahbeq, p 270.

38 Al-Sheikh 'Ali al-Sa'idi al-'Adawi al-Maliki, Hashiyah 'ala Kifayah alTalib al-Rabbani Li Risalah Ibn Abi Zaid al-Qairawani,(Kaherah: Maktabah Mustafa al-Babi al-Halabi, 1938),p 210.

${ }^{39}$ Muhammad Abu Zuhrah,, Muhadarat fi al-Waqf, (Kaherah: Ahmad 'Ali Mukhaimir, (1959), p49.

40 Muhammad Abu Zuhrah, p 106.

41 Asharaf Mohd Ramli,, and Abdullah Jalil. "Corporate Waqf Model and Its Distinctive Features: The Future of Islamic Philanthropy." In World Universities Islamic Philanthropy Conference. Menara Bank Islam, Kuala Lumpur, Malaysia. 2013, p 10.

42 Abdullah Jalil and Asharaf Mohd Ramli, "Conceptualisation Of Corporate Waqf".Seminar Waqf Iqlimi , (2014). 
Nur Hospital, Children's Home Orphans \& Poor Darul Hanan. ${ }^{43}$ This flexibility will give them greater motivation to engage in corporate waqf activities and provide more space for compliance with the Shariah.

Meanwhile, under Section 44(6), there is no two-way ownership. Once the donor contributes to the charitable organisation, it is channelled for charitable activities.

\section{4) Investment}

Jurists have a number of approaches about the investment of waqf; however, the prevailing approach is that the surplus should be invested even if the waqf is for the benefit of a mosque. The administrator should use it to purchase real estate, and if the ruler decides it should be turned into a waqf for a stipulated group of beneficiaries, it will become a waqf. This is the opinion transmitted from Imam al-Ghazali. ${ }^{44}$ The resolution of the First Seminar on Waqf Fiqh Issues stated that it is permissible to invest the surplus proceeds after the proceeds have been distributed to the beneficiaries, and the expenses and allocations have been deducted. The previously mentioned resolution of the Council of the International Islamic Fiqh Academy (IIFA), of the Organization of Islamic Cooperation (OIC), affirmed the same in 2004.

In Malaysia, the Fatwa Committee of the National Council for Islam confirmed the legality of cash waqf during its 77th meeting on 10 to 12 April 2007 under the 9th Malaysia Plan. Based on the opinion of the majority of jurists from Malikis, Shafi'es and Hanbalis, cash waqf may be subject to a non-preservation element of its corpus if it can be transferred to a sustainable asset. ${ }^{45}$ Khaf's definition

${ }^{43}$ One of company's constitutions to provide corporate social responsibility program based on Syariah principle. See http://www.wancorp.com.my/pages.aspx?Content_Name=latar-belakang.

${ }^{44}$ Al-Manawi, 1998: 2/316-317.

${ }^{45}$ Ellias, M., Kadir, A., \& Harun, M, "Cash Waqf and Its Operational Issues: An Analysis from The Islamic Perspective. In International Conference on Cash Waqf: Towards the Implementation of Cash Waqf, (2015); 28-30. 
insists on the subject matter of waqf to be any property, capable of perpetual existence or of repetitive use, or capital being used for profitable investment and productive utilization. ${ }^{46}$

The main aspect deserving mention is the permanence or perpetuity of waqf, i.e., it should be of a lasting nature. The result of this function is that the first priority in the expenditure of waqf revenue must be to preserve and sustain it in order to ensure that its services continue. However, donations under Section 44(6) restrict the charitable organisation to invest in any activities unless approval was given to them and in the case of building acquisition, the institution would have to obtain approval from the Director General of Inland Revenue.

\section{5) Cash and kind}

The subject matter of Waqf can be classified into three forms in general which are al-A'qar, al-Manqul and Waqf al-Irsod. ${ }^{47}$ Al A'qar is the immovable assets or any asset that cannot be moved, relocated or changed. The second category is al-Manqul or a movable asset which refers to asset or possessions that can be moved, for example cash, book, table, chairs, agricultural equipment, poultry, etc. Lastly, al-Irsod refers to the form of waqf where the government of the country has put a piece of property to be used for the benefit of the citizens. Such resources must be used for the best interests of the community and for the benefit of Islam. ${ }^{48}$ Donations under Section 44(6) must be in cash and supported by official receipts for the purpose of tax deduction.

${ }^{46}$ Monzer Kahf,,Al-Waqf al-Islami, Tatawurruhu, Idaratuhu, Tanmiyatuhu. (Dar al-Fikr, Damshiq, 2000).

${ }^{47}$ Abdul Fatah Khalid, "Islamic Law and Land in the State of Selangor, Malaysia: Problems of Administration and Islamisation". (Phd Thesis, University of Edinburgh, 1988).

${ }^{48}$ Noor Aimi Mohd Puad, Nurauliani Jamlus Rafdi, Wan Shahdila Shah Shahar, "Issues and Challenges of Waqf Instrument: A Case Study In MAIS", E-proceedings of the Conference on Management and Muamalah (CoMM 2014), p26. 


\section{6) Objective}

Since the creation of waqf is a voluntary act based on the principle of the owner's freedom to do whatever he or she wants with his or her property, the conditions stated by the donor must be fulfilled as long as they do not contradict or infringe any of the Shariah decisions. This ensures that the income from waqf should be used solely for the purpose set by the donor. In addition, the objectives of the donors may not be changed by the Islamic religious authority as long as they are still feasible to execute. If the objective of the waqf becomes unfeasible, the income of the Waqf should be spent on the next possible purpose and goes to the poor and needy.

However, section 44(6) restricts the charitable organisation to do Islamic charity activities, unless an approval is given by the Director General of Inland Revenue.

\section{7) Purchase and disposal of asset}

Generally, a waqf may not be sold once it is dedicated particularly in situation where state enactments do not allow it. Irrespective of the absence of statutory provision for substitution, waqf in itself prohibits sale of a dedicated asset. Secondly, a waqf property may be declared as a heritage property and restrictions placed on its disposal or sale. ${ }^{49}$ However, some state enactments allow sale or substitution of waqf asset. For example, section 19 of the Wakaf (State of Selangor) Enactment 1999 confers the following power to the SIRC:

The Majlis may istibdal any mawquf in the following circumstances (a) the mawquf has been acquired by any public authority in accordance with the provisions of any written law; (b) the mawquf does not yield any usufruct or benefit as intended by waqif; or (c) if the use of the mawquf does not comply with the purpose of the wakaf.

In certain circumstances, the dedicated asset can be sold with the condition that the consideration received from the sale must be of a

\footnotetext{
${ }^{49}$ MASB Research Paper, Waqf.
} 
higher value than the existing dedicated asset. The consideration may be in cash or another asset.

On the other hand, any charitable organisation approved under Section 44(6) may seek the DGIR's approval for any transaction such as purchase and disposal of an asset.

\section{8) Winding up and Dissolution}

In particular, no immovable property of a waqf shall be transferred by way of sale, gift, mortgage, exchange or lease. The Department of Awqaf, Zakat, Hajj exemplifies waqf as a private possession or asset in any form that has been put under injunction from any transaction including sale, inheritance, hibah, and wassiyyah while its physical sources remain intact and unchanged. As opposed to charitable organisations under Section 44(6) of which in the event of winding up and dissolution, all debts and liabilities legally incurred on its behalf shall be entirely discharged and the balance of the assets shall be donated to any charity or institution approved by the DirectorGeneral of Inland Revenue, as the general meeting may decide. Any part of the company's property or assets shall not be allocated to the company's shareholders and executive board.

\section{9) Building purposes}

Waqf for building purposes is not in line with Section 44(6) because it is free to build permanent and sustainable assets as long as there is an added value to maintain the waqf property. Meanwhile, charitable organisations approved under Section 44(6) require special application and documentation for building purposes.

The justifications above clearly explain the different criteria of waqf and donation under Section 44(6) ITA. For the purpose of tax deduction and exemption, specific provision on waqf should be included in the ITA to ensure that waqf properties do not violate Shari'ah rulings and also to preserve the solidarity of a multi-racial society such as Malaysia. 


\section{TAX TREATMENT FOR WAQF IN SECTION 44(11C) WAQAF AN NUR CORPORATION BERHAD.}

This part examines the tax deduction provided in of Section 44, paragraph 11c of the ITA and its relevance to tax exemption granted to Wakaf An Nur Corporation Berhad. Section 44(11c) prescribes that the deduction shall be deducted from the aggregate income of the person for the year concerned, in accordance with subsection (1) An amount equitable to any gift of money or contribution in kind made by the person concerned for any programme of national interest approved by the Minister. It is provided that the amount to be deducted pursuant to this subsection shall not exceed- (a) in the case of a person other than a company, the difference between the amount of seven per cent of the aggregate income of that person in the relevant year and the total amount that has been deducted pursuant to the proviso to subsections (6) and (11B) for that relevant year; or (b) in the case of a company, the difference between the amount of ten per cent of the aggregate income of that company in the relevant year and the total amount that has been deducted pursuant to the proviso to subsections (6) and (11B) for that relevant year.

Waqaf An Nur Corporation Berhad (WANCorp) has recently been granted a tax exemption status by the Minister of Finance under this provision. The approval for tax exemption is for five years from 1st January 2015 until 31st December 2019.

The conditions for approval under subsection 44 (11c) of ITA 1967 for shares held are as follows:

i. WANCorp shall provide separate accounts for the purpose of receipt of the acceptable shares and issue receipts to all contributors for the purpose of claiming income tax deduction. The receipt shall include a letter of reference for the approval of the Ministry of Finance.

ii. All benefits from shares shall be used solely for the purpose of performing WANCorp functions only.

iii. The company or individual who bought the shares offered is eligible for tax deduction for the period from 1 January 2015 to 31 December 2019. However, tax deduction is subject to a 7 per cent tax deduction from the aggregate income of individuals and 10 per 
cent of the aggregate income of the company subject to section 44 (11C) (a) (b) of the ITA 1967.

iv. Participating parties are entitled to claim income tax deduction for the year of assessment where the shares are reserved only.

v. The allowable contribution for tax deductions is in the form of shares only.

vi. WANCorp shall prepare annual activity reports conducted using waqf benefits under WANCorp and submit the reports to the Ministry of Finance every year until the expiration of the exemption period.

vii. WANCorp shall also provide a list of beneficiaries with the address, date of receipt of contributions, amount of contribution and serial number of receipts issued to donors and submit the list to the Ministry of Finance for each year of assessment until the expiration of the exemption period.

viii. WANCorp should also submit expenditure reports for special funds that are re-invested to the Ministry of Finance annually until the exclusion period and;

ix. At least 50 per cent of the board of director of WANCorp must consist of independent individuals who have no relations with WANCorp, Johor Corporation Group and Johor State Religious Councils.

Although the conditions for approval set by the Ministry of Finance is rather strict, these conditions could be met by waqf organisations that wish to obtain tax exemption for any waqf exercise.

\section{CURRENT PROGRESS ON GOVERNMENT INITIATIVE TO EXCLUDE WAQF FROM TAX}

To date, there is no single provision in ITA 1967 on income tax exemption for waqf. However, on 13 October 2019, Ministry of Finance had announced in Budget 2020 that the tax deduction is applicable to cash waqf which is religious fund contributions to state 
religious authorities or bodies set up by the state religious authorities administering the waqf..$^{50}$

In order to encourage charitable work, the tax reduction on donations for welfare and sports activities, and national interest initiatives currently restricted at 7 per cent from the aggregate income for individuals other than companies, will be raised to 10 per cent in accordance with the business threshold ${ }^{51}$.

At present, income tax exemptions have been granted for all income received by religious organisations or institutions set up specifically for the purpose of religious worship and registered with the Malaysian Registrar of Societies. From 2020 onwards, the tax exemption will be widened to institutions registered as companies limited by a guarantee under the Companies Act 2016

The Inland Revenue Board is still in the process of making public ruling on these matters but it has yet to decide on the inclusion of tax deduction for waqf contribution under the ITA. This tax deduction for waqf contribution may be applied on a temporary basis for five years from 2020 until 2025 and subject to renewal. ${ }^{52}$

\section{CONCLUSION}

Waqf is one of the wealth management mechanisms which helps to contribute to the social wellbeing for the nation particularly in a country where the majority of the population are Muslims. At the university level many of the students particularly from among the B40 have benefited from waqf. During the global COVID-19 pandemic, many universities had initiated various forms of fundraising in order to help students to overcome their financial

50 N.a, “2020 Budget: RM20M For Expading inmates' TVET Skill”, The Sun Daily, 12 October 2019. https://www.thesundaily.my/local/2020budget-rm20m-for-expanding-inmates-tvet-skills-AJ1478002.

51 This was included in the amended Guideline For Approval of Director General of Inland Revenue under Subsection 44(6) of Income Tax Act 1967 Dated 30 January 2020 under Paragraph 10(3)ii.

52 Proposal from IRB to pass public ruling date 16 October 2019- if there is contrary, the updated public ruling or guideline passed by IRB is prevail. 
constraints. These contributions from the public should be given "taxfree-status" in order to encourage more people to come forward to offer help to the needy students.

The compatibility analysis between donation under Section 44(6) ITA 1967 and waqf under Islamic law shows that there are various obstacles to granting tax exemption to waqf similar to charity. This is due to the fact that waqf deals with religious norm and it is difficult to be adopted in a multiracial country such as Malaysia. The way forward could be the establishment of comprehensive waqf guideline by IRB for tax purposes. In Budget 2020, Ministry of Finance had announced that cash waqf contribution will get tax deduction but the IRB is yet to pass public ruling or guideline on this matter. Therefore, it is hoped that in pursuant to this budget allocation, it will be possible to exclude waqf from tax to ensure the continuity of charitable giving by the individuals and corporations. 